\title{
Differences in follicular function of 3-month-old calves and mature cows
}

\author{
M. A. Driancourt ${ }^{1 *}$, K. Reynaud ${ }^{1}$ and J. Smitz ${ }^{2}$ \\ ${ }^{1}$ INRA-URA CNRS 1291, PRMD, 37380 Monnaie, France; and ${ }^{2}$ AZ-VUB, Centre for \\ Reproductive Medicine, Vrije Universiteit Brussel, Laarbeeklaan 101, B-1090 Brussels, Belgium
}

After in vitro maturation, fertilization and development, the percentage of fertilized eggs developing to the blastocyst stage is usually lower in calves compared with cows. It is unknown whether this low ability to develop in vitro is inherent to calf oocytes or is caused by altered follicular maturation. The latter possibility was explored in the present study using two markers of follicle function: in vitro steroidogenesis by intact follicles and aromatase activity of follicular walls. Calf follicles $>9 \mathrm{~mm}$ in diameter had a low ability to produce oestradiol (ten times reduction compared with cows) despite a testosterone output by theca cells which was similar to that observed in cows. This finding is in agreement with the low aromatase activity of granulosa cells of calf follicles measured by tritiated water release assay. Qualitative and quantitative differences between calf and cow follicular fluids were assessed using western blotting (inhibin and activin, heat shock protein 90, Müllerian inhibiting substance) and assays (inhibin and activin) to determine whether this defective aromatase could be produced by alterations in the amounts of follicular proteins modulating aromatase (inhibin and activin, heat shock protein 90, Müllerian inhibiting substance). Western blotting of follicular fluid proteins demonstrated three main bands $(59,57$ and
$<30 \mathrm{kDa})$ and one minor band ( $34 \mathrm{kDa})$ with the anti- $\alpha$ inhibin antibody, whereas a single $18 \mathrm{kDa}$ band was detected when an anti- $\beta$ inhibin antibody was used. Calf follicular fluid contained similar amounts of all main inhibin forms ( $\alpha$ and $\beta$ ) but a $34 \mathrm{kDa} \alpha$ inhibin form was missing. The amounts of dimeric inhibin were similar between cows and calves but small follicles from calves contained more activin. Single bands at $70 \mathrm{kDa}$ (Müllerian inhibiting substance) and $90 \mathrm{kDa}$ (heat shock protein 90) were detected by western blotting. Müllerian inhibiting substance was missing from calf follicular fluid and heat shock protein 90 was present in smaller amounts in calf versus cow follicular fluid. None of the above differences could explain the defective aromatase of calf follicles. Two-dimensional separation of the $\left[{ }^{35} \mathrm{~S}\right]$-labelled proteins secreted by follicular walls originating from calf or cow follicles matched for size and follicle health was performed and 151 spots were observed on the master gel, which summarized all the spots present at least once. Fifteen spots were present in calves and not in cows. Quantitative differences were also detected with three spots containing more proteins in cows than in calves. Whether some of these proteins can alter maturation of follicles or oocytes requires further investigation.

\section{Introduction}

The ovaries of calves contain large numbers of growing and large follicles (Erickson, 1966), the largest of which have a wave-like pattern of growth (Adams et al., 1994; Evans et al., 1994). The use of oocytes contained in some of these follicles could increase the rate of genetic gain in livestock breeding programmes through a reduction of the generation interval (Betteridge et al., 1989; Georges and Massey, 1991). Indeed, these oocytes have the potential to resume meiosis, reach metaphase II and be fertilized (Armstrong et al., 1992, 1994; Duby et al., 1995; Revel et al., 1995). However, after development in vitro, the percentage of

*Present address: Intervet Pharma R\&D, BP 67131, 49071 Beaucouzé, France

Email: marc-antoine.driancourt@intervet.com fertilized eggs developing to the blastocyst stage is usually lower in calves compared with cows (Kajihara et al., 1991; Levesque and Sirard, 1994; Duby et al., 1995, 1996; Revel et al., 1995), although a few studies did not confirm this finding (Armstrong et al., 1992; Irvin et al., 1993). Treatment with exogenous gonadotrophins does not improve the ability of fertilized eggs of calves to develop to the blastocyst stage (Revel et al., 1995). In contrast, ageing of calves was associated with improved rates of development (Pressice et al., 1997).

The low ability of calf oocytes to develop may be a consequence of inherent defects in oocyte development or function (Khatir et al., 1997). Alternatively, an altered follicular maturation, which would decrease the ability of the oocyte to develop, is suggested by the reduced cytoplasmic maturation of oocytes matured in the presence of calf follicular fluid (Khatir et al., 1997). The aim of the 
present study was to assess in more depth whether follicular maturation is altered in calves aged 3 months compared with mature cows.

Steroidogenesis of cow and calf follicles has not been characterized fully. Defective steroidogenesis could alter oocyte function, as the ability to develop to the blastocyst stage after in vitro maturation (IVM) and fertilization (IVF) appears to be related positively to oestradiol concentrations in follicular fluid (Moor and Trounson, 1977) and related negatively to androgen concentrations in follicular fluid (Andriesz and Trounson, 1995). Evans et al. (1994) presented preliminary evidence for defective steroidogenesis in young calves by showing that increasing age of calves was associated with increased oestradiol output by mature follicles. However, because androgen concentrations were not measured in the above study, it is still unclear whether the reduced output of oestradiol by calf follicles is generated by a reduced aromatase or a lack of substrate (testosterone, androstenedione) for aromatase. These possibilities were investigated in the first part of the present study.

The reasons why aromatase activity is reduced in calf follicles were also investigated: (i) by measuring the amounts of particular proteins known to regulate aromatase (inhibin and activin, Müllerian inhibiting substance, heat shock protein 90 (hsp 90)) (Hillier and Miro, 1993; Di Clemente et al., 1994; Driancourt et al., 1999) in calf and cow follicular fluid using western blotting and specific assays (inhibin and activin); and (ii) by a broader approach: two dimensional SDS-PAGE. Such a technique, combined with image analysis, is a potent tool to identify differences between groups without making assumptions about their identity as, in sheep follicles, $>100$ protein spots could be compared between genotypes (Driancourt et al., 1996a).

\section{Materials and Methods}

\section{Animals}

Ovaries from crossbred calves $(n=28)$ were obtained at a local abattoir and were used in Expt 1, whereas 17 calves, mostly Holstein-Friesian ones raised at INRA, were used in Expt 2. At the time the calves were killed their mean age was about 3 months and body weight of calves ranged from 112 to $198 \mathrm{~kg}$ (mean \pm SEM: $158 \pm 5 \mathrm{~kg}$ ). The ovaries of adult cows $(n=20)$ were also obtained from the abattoir. No knowledge of their breeding history was available, but all of the cows were cyclic, as observed by the presence of active or regressing corpora lutea on their ovaries.

\section{Follicular fluid obtention, determination of aromatase activity and histological status of the follicles (Experiment 1)}

Within $30 \mathrm{~min}$ after death, the ovaries of calves and cows were taken back to the laboratory and the largest follicle, when $>5 \mathrm{~mm}$ in diameter, was dissected and measured. If two follicles of a particular animal were the same size, both of them were included. Follicular fluid was then aspirated carefully and frozen immediately for analysis of inhibins (western blotting and assays), Müllerian inhibiting substance and hsp 90 (western blotting). Each follicle was then divided into two follicular walls. The first follicular wall was fixed immediately in Bouin Hollande's solution, processed for histological examination and stained with Shorr stain. Pycnotic bodies, which are markers of granulosa cell apoptosis, were searched for along and within the follicular wall at $\times 400$ magnification. A follicle was said to be atretic if more than five pycnotic bodies were counted on the section studied. The other follicular wall was used to measure aromatase activity. The test system used was the conversion of $1 \beta 2 \beta\left[{ }^{3} \mathrm{H}\right]$ testosterone (NEN, Les Ulis) to ${ }^{3} \mathrm{H}_{2} \mathrm{O}$ when aromatization proceeds. Details on the validation of this procedure for cattle follicles are provided by Thatcher et al. (1991). Briefly, at the initiation of culture, $35 \mathrm{ng}\left[{ }^{3} \mathrm{H}\right]$ testosterone was added to $1 \mathrm{ml}$ minimal essential medium (MEM) containing each follicular wall (one follicular wall per well). Culture was for $3 \mathrm{~h}$ at $37^{\circ} \mathrm{C}$ in an atmosphere of $5 \% \mathrm{CO}_{2}$ in air. At the end of culture, each follicular wall was weighed carefully and the amounts of ${ }^{3} \mathrm{H}_{2} \mathrm{O}$ produced were measured using Sep Pak C 18 columns (Waters, Milford). Aromatase activity was expressed as the ratio between the amount of radioactivity (d.p.m.) in the aqueous phase and the total radioactivity provided per $\mathrm{mg}$ of tissue. This protocol was established to identify an activity of aromatase that could be used to identify atresia in calf and cow follicles.

\section{Follicle culture and determination of aromatase activity (Experiment 2)}

After collection of the ovaries, all follicles $\geqslant 4 \mathrm{~mm}$ in diameter were dissected carefully, measured using a reticule under a dissecting microscope and cultured intact for $1 \mathrm{~h}$ as described by Staigmiller et al. (1982) and Rouillier et al. (1996) for cattle follicles and by Webb et al. (1989) for sheep follicles. In such an incubation system, steroid production is steady for a few hours and relates well to peripheral steroid concentrations (Webb and Gauld, 1985). Follicles were placed in a volume of MEM adjusted to their size according to Rouillier et al. (1996) and incubated in a waterbath maintained at $37^{\circ} \mathrm{C}$ and containing $95 \%$ oxygen. At the end of culture, the media were removed and stored frozen until assayed for oestradiol and testosterone (see below). Follicular fluid was aspirated and the empty follicle was divided into two follicular walls. One follicular wall was used to analyse the two-dimensional pattern of follicular proteins (see below) and the other was used to measure aromatase activity (as described for Expt 1) as a tool to identify healthy versus atretic follicles. There is a tight link between initiation of atresia and a fall in aromatase mRNA (Tilly et al., 1992) and protein (Driancourt et al., 1996b) content. 
Analysis of inhibin, activin, Müllerian inhibiting substance and hsp 90 by western blotting

Individual samples of calf and cow follicular fluid of known origin (follicle size and health status) $(n=22$ per group) obtained in Expt 1 were fractionated by SDS-PAGE under reducing conditions. In addition, a control sample of cow follicular fluid was run on each gel to ascertain the coefficient of variation across all blots. Proteins were electrotransferred onto a nitrocellulose filter $(0.2 \mu \mathrm{m}$ pore size) overnight at $4^{\circ} \mathrm{C}$. After electrotransfer, the filters were incubated for $2 \mathrm{~h}$ at room temperature with $20 \mathrm{mmol}$ Tris-buffered saline (TBS) $\mathrm{I}^{-1}, \mathrm{pH} 7.6$, containing $10 \%(\mathrm{w} / \mathrm{v})$ non-fat dry milk powder (NFDMP) and $0.2 \%(\mathrm{w} / \mathrm{v})$ Tween 20 to saturate non-specific binding sites. Thereafter, filters were incubated for $1 \mathrm{~h}$ at $37^{\circ} \mathrm{C}$ with primary antibodies (monoclonal antibody against human $\alpha$ or $\beta$ A inhibin) (Serotec, Oxford) at a final dilution of 1 in 750. The $\alpha$ inhibin antibody is specific for the $\alpha$ subunit of inhibin, whereas the $\beta$ inhibin antibody recognizes the $\beta A$ and $\beta B$ subunits of inhibin (Groome, 1991). The filters were washed twice in TBS containing 10\% (w/v) NFDMP and $0.2 \%(\mathrm{w} / \mathrm{v})$ Tween 20 . The filters were then incubated for $1 \mathrm{~h}$ at $37^{\circ} \mathrm{C}$ in TBS containing $5 \%(\mathrm{w} / \mathrm{v})$ NFDMP and $0.05 \%$ $(\mathrm{w} / \mathrm{v})$ Tween 20 and peroxidase-labelled rabbit anti-mouse IgG (final dilution 1 in 1000). The filters were again rinsed twice in TBS containing $10 \%(\mathrm{w} / \mathrm{v})$ NFDMP and $0.2 \%$ $(\mathrm{w} / \mathrm{v})$ Tween 20. The signal was revealed by enhanced chemiluminescence (ECL; Amersham, Les Ulis). The coefficient of variation across the four blots of the control sample of cow follicular fluid was $14.3 \%$ when using the $\alpha$ inhibin antibody. The same procedure was followed to detect Müllerian inhibiting substance and hsp 90 using a monoclonal antibody against Müllerian inhibiting substance (1 in 500: provided by B. Vigier, France) and a polyclonal antibody against hsp 90 (1 in 500: provided by C. A. Anderson, USA). Peroxidase-labelled secondary antibodies were obtained from Biosys (Compiegne) (rabbit anti-mouse) and Sanofi diagnostics Pasteur (Amilly) (goat anti-rabbit).

\section{Assays for dimeric inhibin and activin A}

Dimeric inhibin $A$ and activin $A$ were measured using specific enzyme-linked immunosorbent assay kits (Serotec) according to the manufacturer's instructions. These assays are based on the methods described by Groome et al. (1994) and Knight et al. (1996). For the inhibin and activin assays, samples and standards were diluted in fetal calf serum and 5\% BSA in PBS, respectively. Crossreactivities for the dimeric inhibin assay were undetectable for inhibin $B$, whereas for the activin assay they were undetectable for inhibin $A$ and $B$, activin $B$ and follistatin while limited to $1-5 \%$ with activin $A B$. Interference of follistatin or $\alpha_{2}$ macroglobulin in the assays was avoided by pretreating samples with SDS and boiling at $100^{\circ} \mathrm{C}$, followed by oxidation using $\mathrm{H}_{2} \mathrm{O}_{2}$. The sensitivities of the assays were $<0.1 \mathrm{ng} \mathrm{ml}^{-1}$ and $<10 \mathrm{pg} \mathrm{ml}^{-1}$ for the inhibin and activin assays, respectively. Intra-assay coefficients of variation were $<7 \%$ over the working range of the assays.

\section{Neosynthesized proteins and two-dimensional PAGE}

All follicular walls were transferred to new 24-well plates containing $1 \mathrm{ml}$ MEM supplemented with $1 \%(\mathrm{w} / \mathrm{v})$ polyvinyl alcohol (Sigma, St Quentin Fallavier) and devoid of methionine. $\left.{ }^{35} \mathrm{~S}\right]$ methionine (NEN) $(50 \mu \mathrm{Ci}$ per well) was added and follicular walls (one per well) were incubated for $24 \mathrm{~h}$ in the same conditions as before $\left(37^{\circ} \mathrm{C}, 95 \% \mathrm{O}_{2}\right)$. This high oxygen pressure is necessary to prevent development of apoptotic cells within the follicular wall (Terqui et al., 1988). Protease inhibitors (phenyl methyl sulphonyl fluoride (PMSF) to $1 \mathrm{mmol} \mathrm{I}^{-1}$ final concentration, benzamidine to $5 \mathrm{mmol} \mathrm{I}^{-1}$ final concentration) were added at the time of collection of medium and the media were stored at $-20^{\circ} \mathrm{C}$ until processed.

The secretion of synthesized polypeptides into culture medium was determined by measuring the incorporation of $\left.{ }^{35} \mathrm{~S}\right]$ methionine into non-dialysable macromolecules. Culture medium was dialysed extensively against deionized water using dialysis tubing with a molecular mass exclusion limit of 6-8 kDa. Radioactivity in the retentate was determined by scintillation spectrometry.

PAGE was performed in the presence of SDS on equal counts of culture medium (200 000 d.p.m.) to enable determination of quantitative and qualitative differences between follicle types. The procedures used were as described by Roberts et al. (1984).

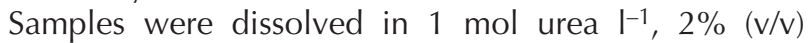
Nonidet P40 (NP40) and 0.5\% (w/v) dithiothreitol. Proteins were resolved in the first dimension by isoelectric focusing in $4 \%(\mathrm{w} / \mathrm{v})$ polyacrylamide tube gels containing $250 \mathrm{~N}-\mathrm{N}^{\prime}-$ diallyltartramide (DADT), $8.0 \mathrm{~mol}^{\text {urea }} \mathrm{I}^{-1}, 2 \%(\mathrm{v} / \mathrm{v}) \mathrm{NP} 40$ and $5.1 \%(\mathrm{v} / \mathrm{v})$ ampholytes $(\mathrm{pH} 3-10)$. This type of wide range ampholytes was selected to visualize as many proteins as possible using isoelectric focusing as the first dimension separation. Tube gels were equilibrated in $50 \mathrm{mmol}$ Tris $-\mathrm{HCl} \mathrm{^{-1 }}, \mathrm{pH}$ 6.8, containing $1 \%(\mathrm{w} / \mathrm{v})$ SDS and $1 \%(\mathrm{v} / \mathrm{v}) \beta$-mercaptoethanol before being subjected to electrophoresis in the second dimension on $10 \%(\mathrm{w} / \mathrm{v})$ polyacrylamide gels in the presence of $0.5 \%(\mathrm{w} / \mathrm{v}) \mathrm{SDS}$. This acrylamide concentration allowed visualization of proteins between $110 \mathrm{kDa}$ and $20 \mathrm{kDa}$. Although gradient gels offer the separation of a wider range of proteins, they were not used in the present study because perfect repeatability (a key issue for image analysis) is difficult to achieve.

Slab gels were stained with Coomassie Blue R 250, destained in acetic acid, ethanol and water, soaked in water, equilibrated with $1 \mathrm{~mol}$ sodium salicylate $\mathrm{I}^{-1}$ (30 min) and dried. Fluorographs were prepared with Kodak XAR X-Ray film and exposed for 3 weeks at $-70^{\circ} \mathrm{C}$. These conditions proved suitable to visualize small spots without saturating the film with large spots.

The fluorographs of the two-dimensional electrophoresis were subjected to qualitative and quantitative analysis using 
Table 1. Amounts of aromatase (tritiated water released per mg of follicular wall, expressed in arbitrary units) of cow and calf follicles shown by histological examination to be healthy or atretic

\begin{tabular}{|c|c|c|c|c|c|c|}
\hline & \multicolumn{2}{|c|}{ Small } & \multicolumn{2}{|c|}{ Medium } & \multicolumn{2}{|c|}{ Large } \\
\hline & Healthy & Atretic & Healthy & Atretic & Healthy & Atretic \\
\hline Cows & $\begin{array}{c}162.5 \pm 69 \\
(n=6)\end{array}$ & $\begin{array}{c}11.0 \pm 4.4 \\
(n=3)\end{array}$ & $\begin{array}{c}195.5 \pm 83.9 \\
(n=6)\end{array}$ & $\begin{array}{c}25.0 \pm 3.7 \\
(n=3)\end{array}$ & $\begin{array}{c}222.8 \pm 72.8 \\
(n=6)\end{array}$ & $(n=0)$ \\
\hline Calves & $\begin{array}{c}11.1 \pm 5.6 \\
(n=5)\end{array}$ & $\begin{array}{c}8.1 \pm 1.6 \\
(n=7)\end{array}$ & $\begin{array}{c}41.5 \pm 0.1 \\
\quad(n=2)\end{array}$ & $\begin{array}{c}10.3 \pm 1.7 \\
(n=3)\end{array}$ & $\begin{array}{c}75.7 \pm 42.8 \\
(n=5)\end{array}$ & $(n=0)$ \\
\hline
\end{tabular}

the Kepler Software (Large Scale Biology, Rockville, TN). Gels were digitized via a charge-coupled device camera (Kodak, Eikonix 1412) serving as scanner; care was taken that saturation was not reached for any of the spots. Scanned gels were then processed for computerized analysis by a Digital workstation 3100. Spots were modelled as Gaussian least squares, so that features of each pattern (position, intensity) were reduced in a spot file. Vertical streaks were removed in an initial step. Matching was then achieved as follows. A general master pattern was obtained by co-migration of all the samples studied. The investigator defined nine key points distributed evenly throughout the gels in the master and in each gel. The Kepler software used these key points to correct for distortion between gels. Automatic matching followed by investigator hand matching (for those spots that were not matched automatically) were then realized. In the final step, minor differences in overall load (as defined by the sum of the darkness of all spots) between gels were corrected automatically to produce accurate measurements of spot intensity (blackening density) in all gels as above.

\section{Steroid assays}

Oestradiol and testosterone concentrations in culture media were quantified by radioimmunoassay (Terqui, 1978; Hochereau-de Reviers et al., 1990). The intra-assay coefficients of variation were 7.7 and $11.5 \%$ for oestradiol and testosterone, respectively. The minimum detectable values for oestradiol and testosterone were $20 \mathrm{pg} \mathrm{ml}^{-1}$ and $0.2 \mathrm{ng} \mathrm{ml}^{-1}$, respectively.

\section{Statistical analysis}

Follicles in Expt 1 were arranged in three size groups (small: $\leqslant 9 \mathrm{~mm}$; medium: 9.5-11.5 mm; and large $\geqslant 12 \mathrm{~mm}$ in diameter) and aromatase activity was compared for healthy follicles of cows versus calves by two-way ANOVA (size effect, group effect and their interaction). In addition, for each group and each size, aromatase activity of healthy follicles (from histological examination) was compared with that of atretic follicles. In Expt 2, steroid concentrations in medium and aromatase activity were analysed using the GLM procedures of SAS (1985). For each of these parameters, the analysis included the group effect, the animal within group effect, the atresia effect and the size by group interaction. Intensity of the signals after ECL visualization of the western blots was measured using the Kepler software as described by Reynaud et al. (1999). A two-way ANOVA was performed to identify differences related to group (cows versus calves), size or their interaction.

Both qualitative and quantitative differences were identified on the two-dimensional gels. Qualitative differences were detected by chi-squared test comparing the frequency of each spot in the two populations (cows versus calves). As six patterns were compared, differences in frequency such as $0 / 6$ versus $6 / 6,0 / 6$ versus $5 / 6,0 / 6$ versus $4 / 6$ and $1 / 6$ versus $5 / 6$ were assumed to be significant $(P<0.05)$. Quantitative differences were identified (by $t$ test) only for spots that were always present in both populations (cows and calves).

\section{Results}

\section{Follicular size, aromatase activity and health status of cow and calf follicles (Experiment 1)}

Twenty-four and 22 follicles were collected from cows and calves, respectively (Table 1). Histological examination of the follicular wall identified six and ten atretic follicles within cow and calf follicles, respectively (Table 1). No atretic follicles were detected in the large size group. When only healthy follicles were considered, the analysis of the changes in aromatase activity related to follicle origin (cow versus calf) or follicle size revealed a highly significant effect of follicle origin $(P<0.02)$ (Table 1$)$ but no size effect or size by origin interaction. In every size class, aromatase was 3-10 times higher in cow follicles (Table 1). Mean aromatase activity of atretic follicles was low (cows: $18 \pm 4.1$; calves: $8.9 \pm 1.2$ arbitrary units). When compared for specific size classes, regardless of the origin (cow versus calf) of the follicles, aromatase activity of atretic follicles was reduced compared with healthy follicles for both small (atretic: $9.0 \pm 1.6(n=10)$; healthy: $93.7 \pm 43.4(n=11))$ $(P<0.05)$ and medium-sized (atretic: $16.6 \pm 3.4(n=6)$; healthy: $157.0 \pm 66.4(n=8))(P<0.01)$ follicles (Table 1$)$. After examination of the individual aromatase data of healthy versus atretic follicles of all sizes in cows and of medium and large follicles in calves, a cut-off level of 25 aromatase units was identified. In cows, this cut-off produced an exact identification of 16 of 17 healthy and 


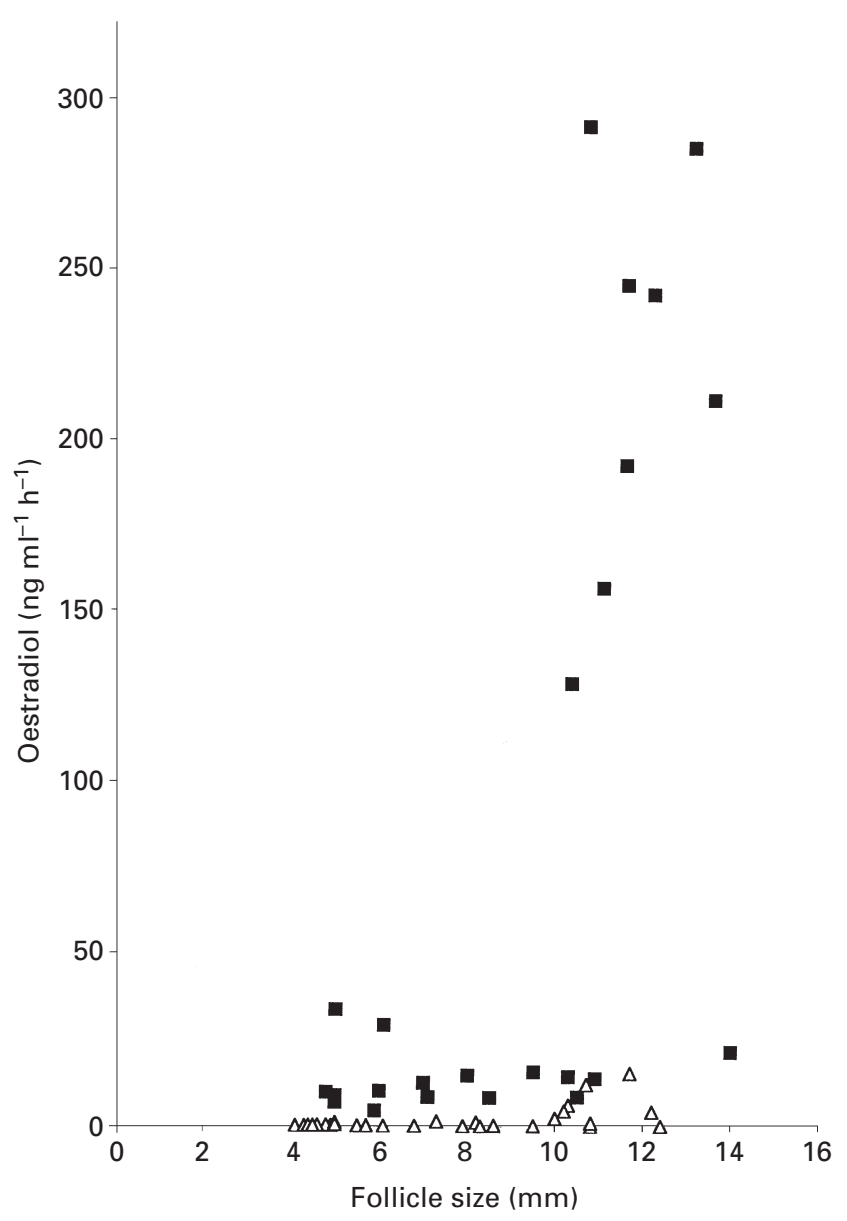

Fig. 1. Size-related changes in in vitro oestradiol output in follicles obtained from cows $(\boldsymbol{\square})$ and calves $(\triangle)$.

five of six atretic follicles. In calves, the same cut-off produced an accurate identification of six of seven healthy and three of three atretic follicles.

\section{Number of follicles and extent of atresia (Experiment 2)}

The ovaries of cows and calves provided $4.5 \pm 0.8$ versus $5.5 \pm 0.5$ follicles $\geqslant 4 \mathrm{~mm}$ in diameter, respectively. The distribution of follicles in size classes was similar in cows and calves. The frequency of atretic follicles with an aromatase activity lower than the cut-off point defined in Expt 1 was similar in calves (61\%) and cows (43\%).

\section{Steroid production by intact follicles in vitro (Experiment 2)}

Steroid production of healthy follicles was compared between groups using a model in which animal within group and size within group were included. No effect of the group (cow or calf) on oestradiol production could be detected. The only effect that was significant was the group by size interaction $(P<0.01)$. This effect was related to the lack of increase in oestradiol output of follicles $\geqslant 10 \mathrm{~mm}$ in diameter in the calves, whereas large amounts of oestradiol are produced by cow follicles when they reach this size

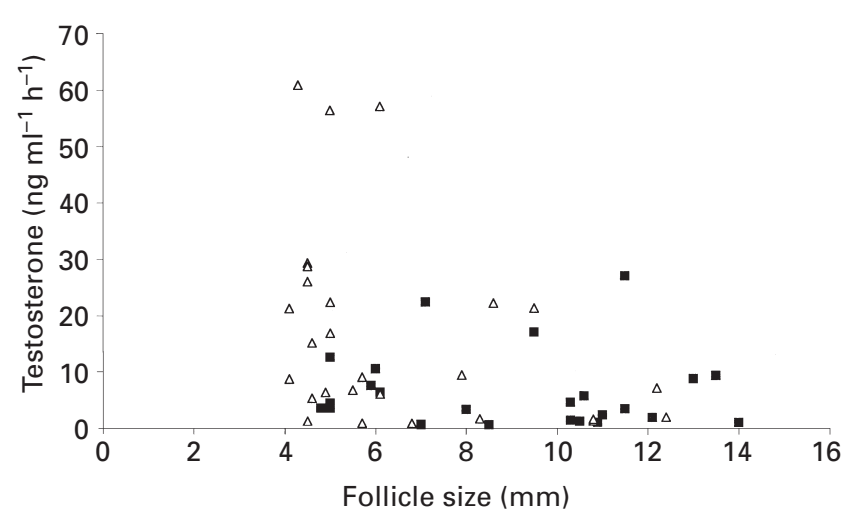

Fig. 2. Size-related changes in in vitro testosterone output in follicles obtained from cows $(\boldsymbol{\square})$ and calves $(\triangle)$.

(Fig. 1). Least squares means for oestradiol production in culture medium were $58.8 \pm 16.6$ and $4.4 \pm 0.8 \mathrm{ng} \mathrm{ml}^{-1}$ $\mathrm{h}^{-1}$ in cows and calves, respectively. Testosterone output was also compared between groups using the same model. Neither the group effect nor the animal within group or size within group effect were significant (Fig. 2). Least squares means for testosterone production in culture medium were $16 \pm 16$ and $41 \pm 20 \mathrm{ng} \mathrm{ml}^{-1} \mathrm{~h}^{-1}$ in cows and calves, respectively.

\section{Analysis of $\alpha$ and $\beta$ inhibin forms by western blotting (Experiment 1)}

A representative immunoblot of cow and calf follicular fluid (Fig. 3) indicates that when the filters were probed with the anti- $\alpha$ inhibin antibody, four bands were detected (at $59,55,34$ and $27 \mathrm{kDa}$ ). When the filters were reprobed with the anti- $\beta$ inhibin antibody, a single band was visualized at $18 \mathrm{kDa}$ (data not shown). Data on the amounts of these signals for healthy follicles and follicle size are shown (Table 2). No effects of follicular origin (cow versus calf), follicle size or follicle size by origin interaction were detected for the $\alpha$ forms at 59, 55 and $27 \mathrm{kDa}$, as well as for the $18 \mathrm{kDa} \beta$ form. The $34 \mathrm{kDa}$ form was restricted to cow follicular fluid (Table 2) and was never present in calf follicular fluid.

In a further analysis, which compared the effects of follicle health (and its interaction with follicle size) of cow or calf follicles, healthy follicles from cows were shown to contain more of the $59 \mathrm{kDa}$ (healthy: $75.6 \pm 10.9$ units; atretic: $25.8 \pm 8.1$ units; $P<0.05$ ) and $55 \mathrm{kDa}$ (healthy: $121.7 \pm 13.6$ units; atretic: $24.8 \pm 13.3$ units; $P<0.01$ ) forms than atretic follicles and similar amounts of $\alpha 34 \mathrm{kDa}$, $\alpha 27 \mathrm{kDa}$ and $\beta$ inhibin. Similar effects of atresia were detected in calf follicles for the $\alpha 59 \mathrm{kDa}$ (healthy: $52.2 \pm 15.0$ units; atretic: $11.1 \pm 1.3$ units; $P<0.01)$ and $\alpha$ $55 \mathrm{kDa}$ (healthy: $110.4 \pm 30.3$ units; atretic: $12.7 \pm 8.7$; $P<0.01)$ forms, although this was confounded by size by atresia interactions approaching significance $(\alpha 55 \mathrm{kDa}$; $P=0.06)$ or reaching significance $(\alpha 59 \mathrm{kDa} ; P<0.05)$. These later findings are produced by a size-related increase 


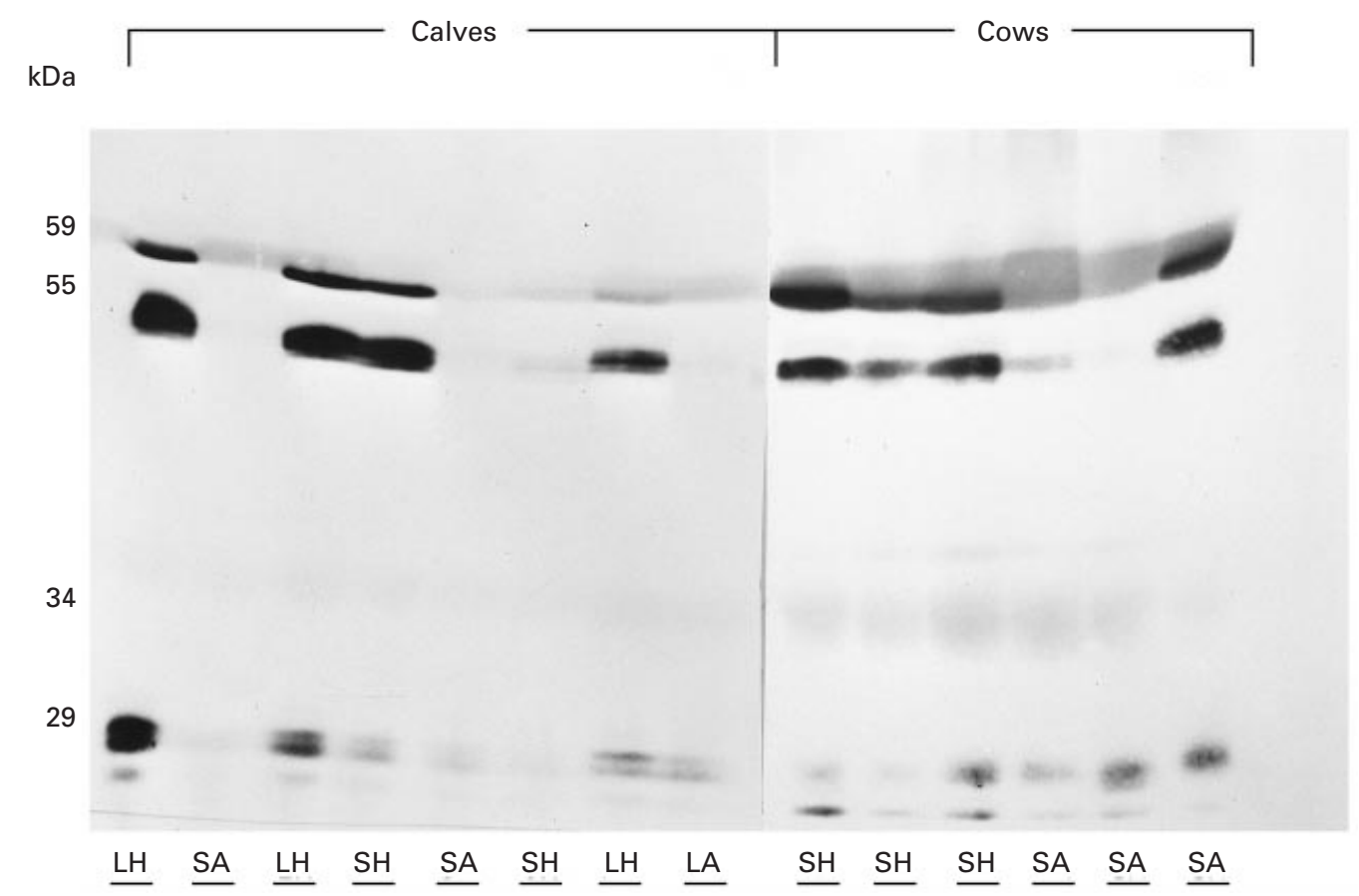

Fig. 3. Immunodetection of $\alpha$ inhibin in follicular fluid originating from large (L) or small (S) follicles obtained from healthy $(\mathrm{H})$ or atretic $(\mathrm{A})$ follicles of calves and cows. Molecular mass markers (kDa) are indicated on the left.

in these compounds in healthy but not in atretic follicles. As in cows, amounts of $\alpha 27 \mathrm{kDa}$ and $\beta$ inhibin were unrelated to follicular atresia.

\section{Dimeric inhibin and activin A assays (Experiment 1)}

The amounts of dimeric inhibin $A$ in follicular fluid were unaffected by follicle origin (calf versus cow) or follicle size and no significant size by origin interaction was detected. Small $(<9 \mathrm{~mm}$ in diameter) follicles contained $373 \pm 72$ and $234 \pm 51 \mathrm{ng}$ dimeric inhibin $\mathrm{ml}^{-1}$ in cows and calves, respectively, whereas follicular fluid from large follicles $(\geqslant 12 \mathrm{~mm}$ in diameter) contained $491 \pm 51$ and $395 \pm 65 \mathrm{ng}$ dimeric inhibin $\mathrm{ml}^{-1}$ in cows and calves, respectively. In contrast, when activin A concentrations were compared between calves and cows, a highly significant interaction $(P<0.01)$ between follicle size and follicle origin was identified. This finding was attributable to the high activin content of follicular fluid from small follicles of calves (5600 $\pm 990 \mathrm{ng} \mathrm{ml}^{-1}$ ) compared with small follicles from cows $\left(3510 \pm 400 \mathrm{ng} \mathrm{m}^{-1}\right)$, whereas large follicles from calves $\left(2430 \pm 300 \mathrm{ng} \mathrm{ml}^{-1}\right)$ and cows $\left(2900 \pm 210 \mathrm{ng} \mathrm{ml}^{-1}\right)$ contained similar amounts of activin. Within small follicles of calves or cows, atresia had no significant effects on the amounts of activin A in follicular fluid (data not shown).

\section{Analysis of Müllerian inhibiting substance and hsp 90 by western blotting (Experiment 1)}

Probing the calf and cow follicular fluid blots with a Müllerian inhibiting substance and hsp 90 antibody resulted in the identification of bands at $70 \mathrm{kDa}$ (Müllerian inhibiting substance) (Fig. 4) and $90 \mathrm{kDa}$ (hsp 90). Quantification of the amounts of Müllerian inhibiting substance present demonstrated that Müllerian inhibiting substance was absent in calf follicular fluid whatever its origin (large versus small follicles, healthy versus atretic follicles). In contrast, cow follicles contained large amounts of Müllerian inhibiting substance $(96.6 \pm 15.4$ pixels). These amounts were unaffected by follicle atresia (healthy: $72.3 \pm 13.3$ pixels; atretic $104.6 \pm 36.8$ pixels) or follicle size. When the effects of the health status (healthy versus atretic), follicle origin (calf versus cow) and the interaction between these two factors on the amounts of hsp 90 present in follicular fluid were examined, neither the main effects nor the interaction were significant. Hence, healthy and atretic follicles were combined to run another ANOVA assessing size effects, follicle origin effects and their interaction. Calf follicles contained significantly less hsp 90 $(16.3 \pm 10.1$ pixels $)$ than did cow follicles $(21.1 \pm 5.5$ pixels), but neither the size effect nor the size by follicle origin interaction was significant.

Patterns of proteins secreted by follicular walls after twodimensional PAGE (Experiment 2)

Only follicular walls (half of the follicle containing granulosa plus theca cells) of healthy follicles (as evidenced by aromatase activity in excess of the cut-off defined in Expt 1) of cows and calves were included in the analysis $(n=6$ follicles in each group). All of the follicles were $9-11 \mathrm{~mm}$ in diameter. 
Table 2. Amounts (pixels $\times 10^{-3}$ ) of the $\alpha$ and $\beta$ inhibin forms detected in follicular fluid of healthy follicles of specific size from calves and cows

\begin{tabular}{|c|c|c|c|c|c|c|}
\hline & Follicle size (mm) & $\alpha 59$ & $\alpha 55$ & $\alpha 34$ & 27 & $\beta$ \\
\hline \multirow[t]{3}{*}{ Cows } & $<9$ & $91.5 \pm 23$ & $107.6 \pm 21$ & $2 \pm 1.5$ & $3.5 \pm 1.7$ & $54 \pm 17$ \\
\hline & $9.5-11.5$ & $61.8 \pm 20$ & $126.2 \pm 32$ & $3.3 \pm 2.4$ & $13.7 \pm 5.7$ & $60.8 \pm 19$ \\
\hline & $>12$ & $73.5 \pm 17$ & $131.3 \pm 20$ & $7.2 \pm 3$ & $28 \pm 14$ & $64.1 \pm 10$ \\
\hline \multirow[t]{3}{*}{ Calves } & $<9$ & $29.8 \pm 22$ & $69.2 \pm 49$ & 0 & $4.6 \pm 4.2$ & $40.4 \pm 11$ \\
\hline & $9.5-11.5$ & $108.5 \pm 49$ & $213.5 \pm 86$ & 0 & $46.5 \pm 43$ & $44 \pm 22$ \\
\hline & $>12$ & $56.4 \pm 19$ & $170 \pm 33$ & 0 & $68.4 \pm 43$ & $69 \pm 23$ \\
\hline
\end{tabular}

With the exception of the $\alpha 34$ band, which was only detected in cows, amounts of signal in all other bands were similar in cows and calves.

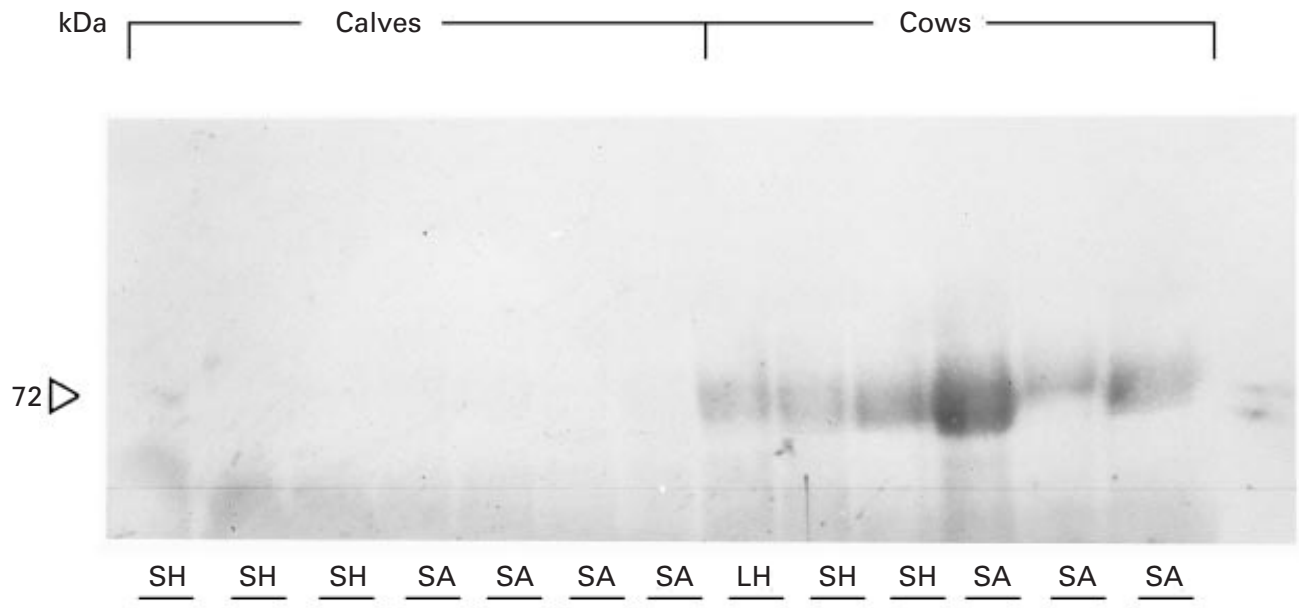

Fig. 4. Immunodetection of Müllerian inhibiting substance in follicular fluid originating from large (L) or small $(\mathrm{S})$ follicles obtained from healthy $(\mathrm{H})$ or atretic $(\mathrm{A})$ follicles of calves and cows. Molecular mass markers $(\mathrm{kDa})$ are indicated on the left.

Representative two-dimensional patterns are shown (Fig. 5). The experimental conditions (concentration of acrylamide and ampholines used) of two-dimensional PAGE enabled visualization of proteins between $20 \mathrm{kDa}$ and $100 \mathrm{kDa}$ with an isoelectric point ranging from 4.5 to 8.2 .

A total of 151 spots could be detected on the master pattern that grouped all spots present at least once in a group (Fig. 6). Examination of qualitative differences revealed that 15 spots $(15,29,41,42,47,49,59,62,71$, 73, 88, 90, 131, 132 and 148) differed between groups. Their physicochemical features and whether they are typical of cow or calves patterns is shown (Table 3). These 15 spots were all are minor spots that did not contain $>2 \%$ of the total of the labelled proteins loaded and none of these spots could be stained with Coomassie blue. Quantitative differences were also identified for three spots (20, 32 and 60). Their physicochemical features, the group in which they are more abundant and the amounts of proteins they contain (pixels) are shown (Table 3). With a few exceptions, most of the spots with qualitative or quantitative differences are members of protein 'trains' grouping spots with close molecular masses and isoelectric points (for example, spots $47,59,62$ and 73 , spots 49 and 71 , spots 20 and 148).

\section{Discussion}

The low ability of calf oocytes to develop to the blastocyst stage has been demonstrated in earlier studies (Kajihara et al., 1991; Levesque and Sirard, 1994; Duby et al., 1995; 1996; Revel et al., 1995). In the present study it was established that: (i) oestradiol output of calf follicles was low because their aromatase activity was reduced markedly; (ii) the amounts of specific $\alpha$ inhibin forms, of Müllerian inhibiting substance and hsp 90 differed in follicular fluid of cows and calves; however, none of these differences are likely to explain the reduced aromatase activity and low oocyte quality of calves; and (iii) fifteen and three spots differed qualitatively or quantitatively when the two-dimensional patterns of follicular proteins of calves and cows were compared.

Follicular steroidogenesis was compared between cows and calves as there are several lines of evidence demonstrating the link between the amounts of steroids present in 
(a) IEF $\longrightarrow+$

$\mathrm{kDa}$

97

68

45

30

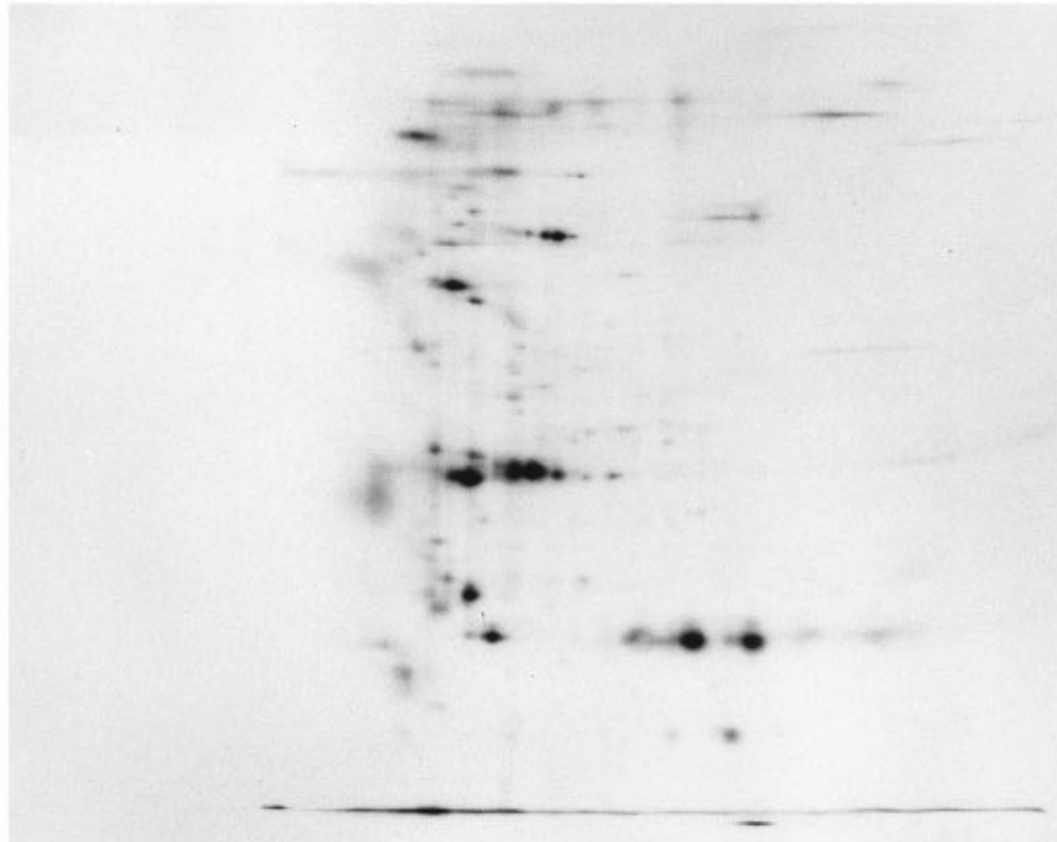

○

(b)

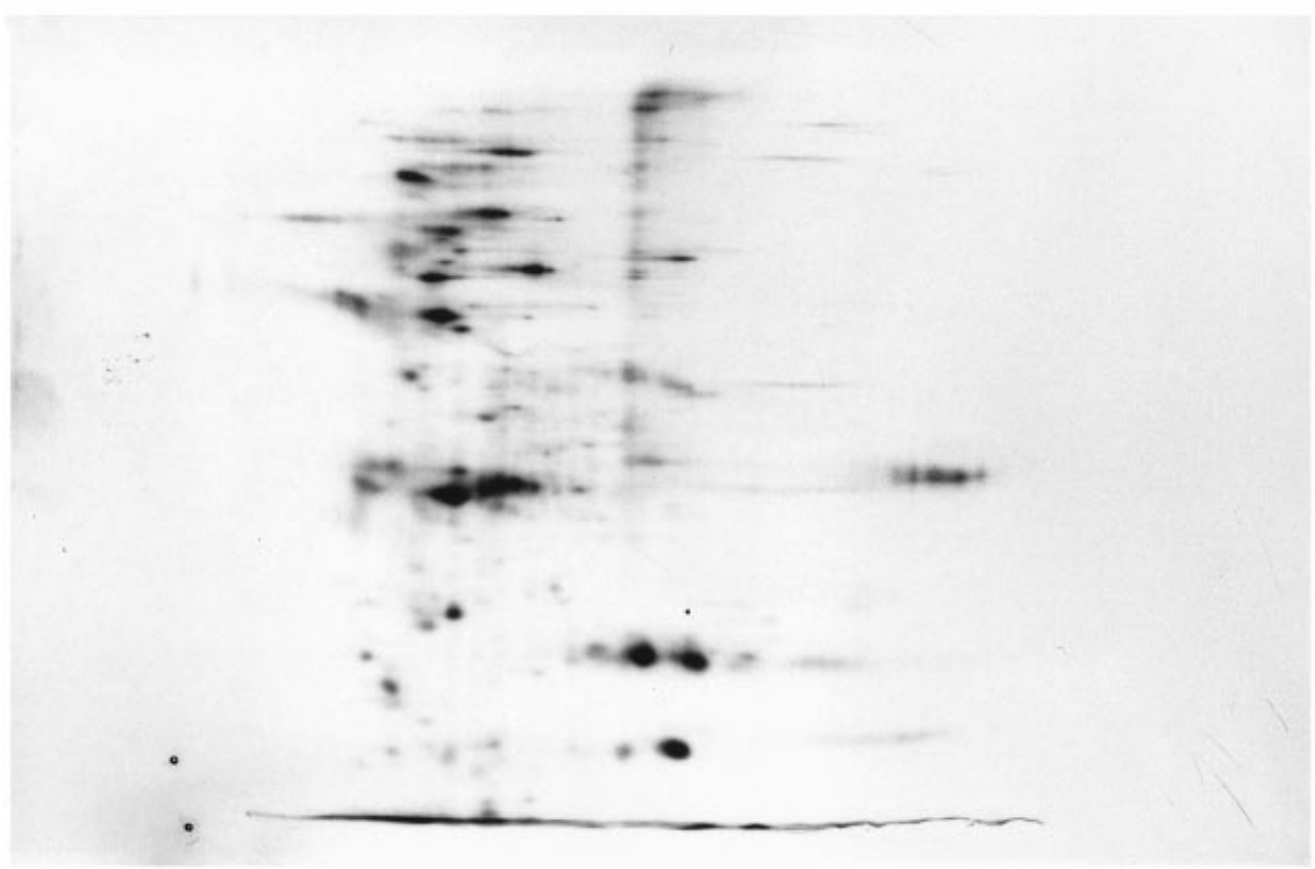

Fig. 5. Representative fluorographs of the two-dimensional pattern of proteins neosynthesized by (a) cow or (b) calf follicular walls. Molecular mass markers are indicated on the left. Acidic and basic sides are indicated at the top of the gel. IEF: isoelectric focusing. 
$\mathrm{IEF} \rightarrow+$

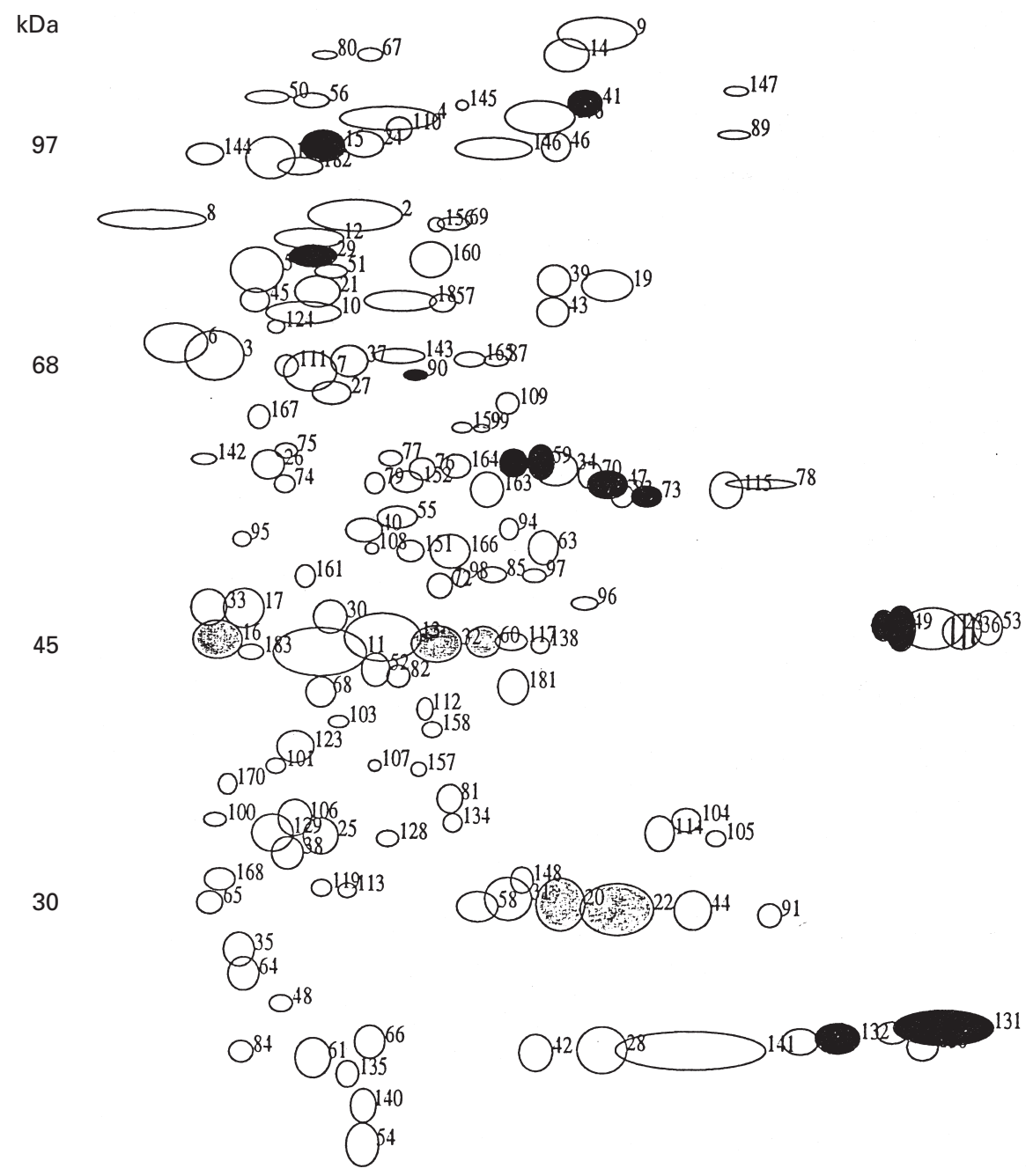

Fig. 6. Qualitative $(\mathbf{O})$ and quantitative (calf $>$ cow; $\mathbb{D}$ ) (cow > calf; (-2) differences in the spots (numbered by Kepler software) detected in proteins secreted by calf and cow follicular walls. Molecular mass markers are indicated on the left. IEF: isoelectric focusing.

follicular fluid and oocyte quality (Moor and Trounson, 1977; Moor et al., 1980; Andriesz and Trounson, 1995). In addition, in primates, administration of an aromatase inhibitor during the follicular phase reduces oocyte quality (Zelinski Wooten et al., 1993). The present work established, using two in vitro approaches, namely the tritiated water release assay and in vitro incubation of intact follicles, that calf follicles had low aromatase activity. Both of these approaches provided similar conclusions. In addition, in vitro incubation of intact follicles showed that thecal function, measured by testosterone output in vitro, was similar in calves and cows. These results regarding aromatase extend earlier findings that suggested that the ability of calf follicles to produce oestradiol might be reduced. Firstly, when studying calves of increasing age, Evans et al. (1994) demonstrated that as the calves grew older their oestradiol output increased. Secondly, attempts to induce superovulation in calves have shown that exogenous LH needs to be given to calves to trigger ovulation (Hafez, 1969; Onuma et al., 1970), again indicating that oestradiol production by large follicles may be insufficient to trigger the $\mathrm{LH}$ surge. In fact, this low aromatase content of follicles of prepubertal animals does not appear to be restricted to calves, as a similar finding has been reported in lambs (McNatty et al., 1986, 1987). FSH (Saumande, 1990) is the key gonadotrophin regulating aromatase. However, it has recently been shown (P. Mermillod, J. J. Dufour and M. A. Driancourt, unpublished) that the defect in aromatase of calf follicles was not corrected by administration of exogenous FSH. This finding indicates strongly that it may have a gonadal (and not central) origin.

The origin of the aromatase defect in calves was explored initially by measuring the amounts of compounds known to 
Table 3. Features of the protein spots qualitatively or quantitatively different between cows and calves

\begin{tabular}{|c|c|c|c|c|c|c|}
\hline \multirow[b]{2}{*}{ Spot number } & \multirow[b]{2}{*}{ Type of difference } & \multicolumn{2}{|c|}{ Frequency } & \multirow[b]{2}{*}{ Molecular mass (kDa) } & \multirow{2}{*}{$\begin{array}{l}\text { Amounts per spot in } \\
\text { cows (arbitrary units) }\end{array}$} & \multirow{2}{*}{$\begin{array}{l}\text { Amounts per spot in } \\
\text { calves (arbitrary units) }\end{array}$} \\
\hline & & Cows & Calves & & & \\
\hline 15 & Qualitative & $0 / 6$ & $4 / 6$ & 95 & 0 & 34100 \\
\hline 29 & Qualitative & $0 / 6$ & $4 / 6$ & 82 & 0 & 51400 \\
\hline 41 & Qualitative & $0 / 6$ & $4 / 6$ & 99 & 0 & 26900 \\
\hline 42 & Qualitative & $1 / 6$ & $5 / 6$ & 24 & 34000 & 52700 \\
\hline 47 & Qualitative & $0 / 6$ & $5 / 6$ & 57 & 0 & 66000 \\
\hline 49 & Qualitative & $0 / 6$ & $6 / 6$ & 45 & 0 & 83000 \\
\hline 59 & Qualitative & $0 / 6$ & $5 / 6$ & 59 & 0 & 69000 \\
\hline 62 & Qualitative & $0 / 6$ & $4 / 6$ & 59 & 0 & 30000 \\
\hline 71 & Qualitative & $0 / 6$ & $4 / 6$ & 45 & 0 & 49000 \\
\hline 73 & Qualitative & $0 / 6$ & $4 / 6$ & 56 & 0 & 29800 \\
\hline 88 & Qualitative & $1 / 6$ & $5 / 6$ & 24 & 32000 & 164000 \\
\hline 90 & Qualitative & $0 / 6$ & $6 / 6$ & 69 & 0 & 31000 \\
\hline 131 & Qualitative & $0 / 6$ & $4 / 6$ & 24 & 0 & 110700 \\
\hline 132 & Qualitative & $0 / 6$ & $4 / 6$ & 23 & 0 & 58000 \\
\hline 148 & Qualitative & $0 / 6$ & $4 / 6$ & 32 & 0 & 49900 \\
\hline 20 & Quantitative & & & 31 & 446000 & $301000^{* *}$ \\
\hline 32 & Quantitative & & & 45 & 360000 & $214000^{*}$ \\
\hline 60 & Quantitative & & & 45 & 153000 & $44000 *$ \\
\hline
\end{tabular}

Qualitative differences were detected by chi-squared test comparing the frequency of each spot in the two populations (cows versus calves). Quantitative differences are shown (by Student's t test) only for spots that were always present in both populations (cows and calves). This is why some of the differences presented in Fig. 6 (for spots 16, 22 and 36) do not appear in this table.

Asterisks indicate values significantly different from corresponding cow value $\left({ }^{*} P<0.05\right.$ and $\left.{ }^{* *} P \leqslant 0.01\right)$.

modulate aromatase (inhibin: Ying et al., 1986; activin: Hillier and Miro, 1993; Müllerian inhibiting substance: Di Clemente et al., 1994; hsp 90: Driancourt et al., 1999). In addition, some of these compounds (inhibin and activin) also affect oocyte quality as demonstrated by the improvement of the percentage of blastocysts obtained after in vitro maturation, fertilization and development when inhibin and activin are added to the maturation medium of cattle oocytes (Stock et al., 1997; Silva and Knight, 1998). The pattern visualized in cow and calf follicular fluid after western blotting with an antibody raised against $\alpha$ inhibin was similar to that described by Hopko Ireland et al. (1994), with major bands at 59 and $57 \mathrm{kDa}$, and low molecular mass $(<30 \mathrm{kDa})$. The effects of atresia were also in good agreement with the earlier report of Hopko Ireland et al. (1994). When the pattern of $\alpha$ inhibin forms was compared for healthy follicles of cows and calves, the only obvious difference was the presence of a form at $34 \mathrm{kDa}$ in cow but not calf follicular fluid. Hopko Ireland et al. (1994) did not identify this $\alpha$ inhibin form. However, after silver staining of follicular fluid samples of calves and cows, Khatir et al. (1996) demonstrated that the latter contained larger amounts of an unknown compound at $34 \mathrm{kDa}$. Further studies are required to determine whether this $34 \mathrm{kDa}$ compound is indeed an $\alpha$ inhibin form. When the same blot was reprobed (after deshybridation) with the $\beta$ inhibin antibody, which recognizes both $\beta A$ and $\beta B$ subunits of inhibin, no difference was found between cows and calves for the amounts of inhibin $\beta$ at $18 \mathrm{kDa}$. Owing to the possible associations between $\alpha$ and $\beta$ subunits, as well as between two $\beta$ subunits producing inhibin and activin, respectively, the actual amounts of inhibin and activin could not be predicted from this approach. Hence, the same samples were assayed for dimeric inhibin and activin A using the enzyme-linked immunosolvent assays developed by Groome et al. (1994) and Knight et al. (1996). Although the amounts of inhibin were unaffected by follicle size and follicle origin (calves or cows), a significant follicle size by follicle origin interaction was detected for the amounts of activin A in follicular fluid. Small follicles from calves contained almost twice the amounts of activin present in small follicles from cows, but this difference was not observed in large follicles. Whether and how this can contribute to the alterations of follicular and oocyte function observed in calves remains to be established. In contrast, Müllerian inhibiting substance and hsp 90, the amounts of which are undetectable (Müllerian inhibiting substance) or lower (hsp 90) in calves than in cows, do not appear to be good candidates to explain the low aromatase activity of calf follicles.

As none of the above differences in the amounts of compounds regulating aromatase could explain the low aromatase activity observed in calves, the last part of the study aimed to establish the two-dimensional pattern of proteins neosynthesized by follicular walls and compare them by image analysis in cows and calves. Such an approach previously proved useful to detect spots related to prolificacy genes in sheep (Driancourt et al., 1996a; 
Reynaud et al., 1999). As the number of spots visualized using this procedure (about 150) is about ten times higher than that reported after one-dimensional PAGE (15-20) (Khatir et al., 1996), the combination of two-dimensional PAGE and image analysis is a very potent procedure to detect differences between samples. Both qualitative $(n=15)$ and quantitative $(n=3)$ differences were detected for compounds ranging from 95 to $23 \mathrm{kDa}$. Many of these differences, located in 'protein trains' are likely to be produced by differences in glycosylation or phosphorylation of proteins, resulting in altered isoelectric points. A major limitation of this approach is that, owing to the high sensitivity of the fluorography and image analysis, it identifies a large number of candidate spots. Interestingly, glutathione peroxidase has a molecular mass and isoelectric points close to those of spots 88, 131 and 132, and is present in epidymal fluid (Fouchecourt et al., 1999). Further work is required to investigate this hypothesis and to obtain sequences of the spots identified in the present study. It will then become possible to determine whether some of these proteins can modulate follicle and oocyte maturation.

The authors are grateful to the staff of the slaughterhouse at INRA or at Tours for provision of ovaries. Help in data analysis of M. Terqui is also gratefully acknowledged, as is provision of the hsp 90 antibodies by C. A. Anderson, USA, and of the MIS antibody by B. Vigier (Paris, France).

\section{References}

Adams GP, Evans ACO and Rawlings NC (1994) Follicular waves and circulating gonadotrophins in 8 month old prepubertal heifers Journal of Reproduction and Fertility $10027-33$

Andriesz C and Trounson A (1995) The effect of testosterone on the maturation and developmental capacity of murine oocytes in vitro. Human Reproduction 10 2377-2381

Armstrong DT, Holen P, Irvine BJ, Petersen BA, Stubbings RB, McLean D, Stevens GF and Seamark RF (1992) Pregnancies and live birth from in vitro fertilization of calf oocytes by laporoscopic follicular aspiration Theriogenology 38 667-678

Armstrong DT, Irvine BJ, Earl CR, McLean D and Seamark RF (1994) Gonadotropin stimulation regimes for follicular aspiration and in vitro embryo production from calf oocytes Theriogenology $\mathbf{4 2} 1227-1236$

Betteridge KJ, Smith C, Stubbings RB, Xu KP and King WA (1989) Potential genetic improvement of cattle by fertilization of fetal oocytes in vitro. Journal of Reproduction and Fertility Supplement 38 87-98

Di Clemente N, Goxe B, Remy JJ, Cate R, Josso N, Vigier B and Salesse R (1994) Inhibitory effect of AMH upon the expression of aromatase and $\mathrm{LH}$ receptors by cultured granulosa cells of rat and porcine immature ovaries Endocrine 2 553-558

Driancourt MA, Gormon T, Phan Thanh L and Boomarov O (1996a) Analysis by two dimensional electrophoresis of proteins secreted by sheep ovarian follicles: effects of the $\mathrm{Fec}^{\mathrm{B}}$ gene, follicle size and atresia Journal of Reproduction and Fertility 107 69-77

Driancourt MA, Paris A and Debrauer L (1996b) Aromatase activity of ovine follicular walls: technical validation and physiological control Reproduction Fertility and Development 8 875-884

Driancourt MA, Guet P, Reynaud K, Chadli A and Catelli M (1999) Presence of an aromatase inhibitor, possibly heat shock protein 90 in dominant follicles of cattle Journal of Reproduction and Fertility $\mathbf{1 1 5}$ 45-58

Duby RT, Damiani P, Looney CR, Long CR, Balise JJ and Robl JM (1995) Cytological characterization of maturation and fertilization in prepubertal calf oocytes Theriogenology 43202 (Abstract)
Duby RT, Damiani P, Looney CR, Fissore RA and Robl JM (1996) Prepubertal calves as oocyte donors: promises and problems Theriogenology $\mathbf{4 5}$ $121-130$

Erickson BH (1966) Development and senescence of the postnatal bovine ovary Journal of Animal Science 25 800-805

Evans ACO, Adams GP and Rawlings NC (1994) Follicular and hormonal development in prepubertal heifers from 2 to 36 weeks of age Journal of Reproduction and Fertility 102 463-470

Findlay JK (1993) An update on the roles of inhibin, activin and follistatin as local regulators of folliculogenesis Biology of Reproduction 48 15-23

Fouchecourt S, Dacheux F and Dacheux JL (1999) Glutathioneindependent prostaglandin $\mathrm{D}_{2}$ synthase in ram and stallion epididymal fluids: origin and regulation Biology of Reproduction 60 558-566

Georges M and Massey JM (1991) Velogenetics, or the use of marker assisted selection and germ line manipulation Theriogenology 35 151-159

Groome NP (1991) Ultrasensitive two site immunoassays for inhibin and activin using monoclonal antibodies raised to synthetic peptides Journal of Immunological Methods 145 65-69

Groome NP, Illingworth PJ, O'Brien M, Cooke I, Baird DT and McNeilly AS (1994) Detection of dimeric inhibin throughout the menstrual cycle by two site enzyme immunoassay Clinical Endocrinology 40 717-723

Hafez ESE (1969) Superovulation and preservation of mammalian eggs Acta Endocrinologica 62 (Supplement 140) 1-39

Hillier SG and Miro F (1993) Local regulation of primate granulosa cell aromatase activity Journal of Steroid Biochemistry and Molecular Biology 44 435-439

Hochereau-de Reviers MT, Copin M, Seck M, Monet-Kuntz C, Cornu C, Fontaine I, Perreau C, Elsen JM and Boomarov O (1990) Stimulation of testosterone production by PMSG injection in the ovine male: effect of breed and age and application to males carrying or not carrying the $\mathrm{F}$ Booroola gene Animal Reproduction Science 23 21-32

Hopko Ireland JL, Good TEM, Knight PG and Ireland JJ (1994) Alterations in amounts of different forms of inhibin during follicular atresia Biology of Reproduction 50 1265-1276

Irvin B, Armstrong DT, Earl CR, McLean D and Seamark RF (1993) Follicle development and oocyte recovery from calves with repeated gonadotropin stimulation and follicular aspiration Theriogenology 39 237 (Abstract)

Kajihara Y, Blakewood EG, Myers MW, Kometari N, Goto K and Godke RA (1991) In vitro maturation and fertilization of follicular oocytes obtained from calves Theriogenology 35220 (Abstract)

Khatir H, Lonergan P, Carolan C and Mermillod P (1996) Prepubertal bovine oocyte: a negative model for studying oocyte developmental competence Molecular Reproduction and Development 45 231-239

Khatir H, Carolan C, Lonergan P and Mermillod P (1997) Characterization of calf follicular fluid and its ability to support cytoplasmic maturation of cow and calf oocytes Journal of Reproduction and Fertility 111 267-275

Knight PG, Muttukrishan S and Groome NP (1996) Development and application of a two site enzyme immunoassay for the determination of total activin A concentrations in serum and follicular fluid Endocrinology 148 267-279

Levesque JT and Sirard MA (1994) Proteins in oocytes from calves and adult cows before maturation: relationships with their developmental capacity Reproduction Nutrition and Development 34 133-139

McNatty KP, Lun S, Health DA, Ball K, Smith P, Hudson NL, McDiarmid J, Gibb M and Henderson KM (1986) Differences in ovarian activity between Booroola Merino ewes which were homozygous, heterozygous and non carriers of a major gene influencing their ovulation rate Journal of Reproduction and Fertility 77 193-205

McNatty KP, Lun S, Heath DA and O'Keeffe LE (1987) Ovarian follicular activity in Booroola lambs with and without a fecundity gene Journal of Reproduction and Fertility 79 57-66

Moor RM and Trounson A (1977) Hormonal and follicular factors affecting maturation of sheep oocytes in vitro and their subsequent developmental capacity Journal of Reproduction and Fertility 49 101-109

Moor RM, Polge C and Willadsen SM (1980) Effect of follicular steroids on the maturation and fertilization of mammalian oocytes Journal of Embryology and Experimental Morphology 56 319-335 
Onuma H, Hahn J and Foote RH (1970) Factors affecting superovulation, fertilization and recovery of superovulated ova in prepubertal cattle Journal of Reproduction and Fertility 21 119-126

Presicce GA, Jiang S, Simkin M, Zhang L, Looney CR, Godke RA and Yang X (1997) Age and hormonal dependence of acquisition of oocyte competence for embryogenesis in prepubertal calves Biology of Reproduction 56 386-392

Revel F, Mermillod P, Peynot N, Renard JP and Heyman Y (1995) Low developmental capacity of in vitro matured and fertilized oocytes from calves compared with that of cows Journal of Reproduction and Fertility $103115-120$

Reynaud K, Hanahan JP, Donovan A and Driancourt MA (1999) Markers of follicle function in Belclare cross ewes differing widely in ovulation rate Journal of Reproduction and Fertility 116 51-61

Roberts RM, Baumback GA, Buhi WC, Denny JB, Fitzgerald LA, Babelyn SF and Horst MN (1984) Analysis of membrane polypeptides by twodimensional polyacylamide gel electrophoresis. In Molecular and Chemical Characterization of Membrane Receptors pp 61-113 Eds CJ Wenter and LC Harrison. AR Liss, New York

Rouillier P, Guilbault LA, Lussier JG and Matton P (1996) Changes in morphological appearance and functional capacity of recruited follicles in cows treated with $\mathrm{FSH}$ in the presence or absence of a dominant follicle Theriogenology 46 1053-1061

SAS (1985) SAS User Guide: Statistics SAS Institute Inc., Cary, NC

Saumande J (1990) Culture of bovine granulosa cells in a chemically defined serum free medium. The effect of insulin and fibromectin on the responses to FSH Journal of Steroid Biochemistry and Molecular Biology 18 189-196

Silva CC and Knight PG (1998) Modulatory actions of activin A and follistatin on the developmental competence of in vitro matured bovine oocytes Biology of Reproduction 58 558-565

Staigmiller RB, England BG, Webb R, Short RE and Bellows RA (1982) Estrogen secretion and gonadotropin binding by individual bovine follicles during estrus Journal of Animal Science 55 1473-1482

Stock AE, Woodruff TK and Smith LC (1997) Effects of inhibin A and activin A during in vitro maturation of bovine oocytes in hormone and serum free medium Biology of Reproduction 56 1559-1564
Terqui M (1978) Contribution à l'étude des Oestrogenes Chez la Brebis et la Truie DSc Thesis, University of Paris

Terqui M, Berthelot F and Driancourt MA (1988) Morphological and functional features of ovine follicles in perfusion with pulsatile hormone delivery Reproduction Nutrition and Development 28 1093-1104

Thatcher WW, Driancourt MA, Terqui M and Badinga L (1991) Dynamics of ovarian follicular development in cattle following hysterectomy and during early pregnancy Domestic Animal Endocrinology 8 223-234

Tilly JL, Kowalski KI, Schomberg DW and Hsueh AJW (1992) Apoptosis in atretic ovarian follicles is associated with selective decreases in messenger ribonucleic acid transcripts for gonadotropin receptors and cytochrome P450 aromatase Endocrinology 131 1670-1676

Webb R and Gauld IK (1985) Genetics and physiology of follicle recruitment and maturation during seasonal anoestrus. In Endocrine Causes of Seasonal and Lactational Anoestrus in Farm Animals pp 19-28. Martinus Nighoff, The Hague

Webb R, Gauld IK and Driancourt MA (1989) Morphological and functional characterization of large antral follicles in three breeds of sheep with different ovulation rates Journal of Reproduction and Fertility 87 243-255

Ying SY, Becker A, Ling N, Veno N and Guillemin R (1986) Inhibin and beta type transforming growth factor (TGF $\beta$ ) have opposite modulating effects on the follicle stimulating hormone (FSH) induced aromatase activity of cultured rat granulosa cells Biochemical and Biophysical Research Communications 139 969-975

Zelinski Wooten MB, Hess DL, Baughman WL, Molskness TA, Wole DP and Stouffer RL (1993) Administration of an aromatase inhibitor during the late follicular phase of gonadotrophin treated cycles in rhesus monkeys: effects on follicle development, oocyte maturation and subsequent luteal function Journal of Clinical Endocrinology and Metabolism 76 988-995

Revised manuscript received 15 September 2000. Accepted 1 November 2000. 